\title{
Same-Session Direct Cholangioscopy Post-Mechanical Lithotripsy
}

\author{
Vincent Zimmer ${ }^{\mathrm{a}, \mathrm{b}}$ \\ ${ }^{a}$ Department of Medicine, Marienhausklinik St. Josef Kohlhof, Neunkirchen, Germany; ${ }^{b}$ Department of Medicine II, \\ Saarland University Medical Center, Saarland University, Homburg, Germany
}

Keywords

Endoscopic retrograde cholangiopancreatography · Bile duct dilation - Biliary stone disease - Direct cholangioscopy

\section{Colangioscopia direta pós litotripsia mecânica na mesma sessão}

\section{Palavras chave}

CPRE · Dilatação via biliar · Litiase biliar · Colangioscopia direta

A 91-year-old female patient with a remote history of cholecystectomy presented with recurrent biliary pain. In the presence of minor laboratory cholestasis (gamma-glutamyl transferase $310 \mathrm{U} / \mathrm{L}$, normal 6-42; alkaline phosphatase $226 \mathrm{U} / \mathrm{L}$, normal 30-104; bilirubin within normal range) and marked bile duct dilation $>30 \mathrm{~mm}$ on abdominal ultrasound, the patient underwent endoscopic retrograde cholangiopancreatography under antibiotic coverage with ceftriaxone in the left lateral position. On cholangiograms, two barrel-shaped stones (the larger one estimated at up to $18 \mathrm{~mm}$ maximum diameter; the smaller one about $12 \mathrm{~mm}$ - not shown) emerged in the distal common bile duct (CBD), necessitating me-

karger@karger.com www.karger.com/pjg

Karger"
C 2020 Sociedade Portuguesa de Gastrenterologia Published by S. Karger AG, Basel

This article is licensed under the Creative Commons AttributionNonCommercial-NoDerivatives 4.0 International License (CC BYNC-ND) (http://www.karger.com/Services/OpenAccessLicense). Usage and distribution for commercial purposes as well as any distribution of modified material requires written permission. chanical lithotripsy after maximum-incision papillotomy (Fig. 1a). With a view to the diffusely dilated biliary system translating into reduced sensitivity to fluoroscopically detect residual stones, the patient underwent direct cholangioscopy using an ultra-slim upper endoscope (outer diameter $5.9 \mathrm{~mm}$ - no $\mathrm{CO}_{2}$ needed for distension). Albeit this might still be debatable, this strategy has become a novel standard in our department. Specifically, this was achieved in a free-hand fashion by the so-called "hooking technique" involving gentle retroflexion in the descending duodenum with entering of the bile duct during scope withdrawal (Fig. 1b). Diffuse mucosa-adherent sludge, inspissated bile as well as disintegrated, pulverized stone material became visible in the pre-papillary CBD, virtually blurring mucosal visualization altogether in this segment (Fig. 1c). However, no circumscript residual stone was detected necessitating dedicated extraction. Further scope advancement to visualize hilar structures failed due to gastric scope looping not to be effectively resolved by manual compression with detection of instrumentation-related self-limited oozing and submucosal hematoma (Fig. 2a). Therefore, the "biopsy-forceps anchoring" method was implemented, resulting in stable scope advancement up to the hilum [1] (Fig. 2b, c). 
Fig. 1. a Cholangiography indicating marked CBD dilation $>30 \mathrm{~mm}$ with a large barrel-shaped stone up to a maximum of 18 $\mathrm{mm}$ prior to capturing it into a Dormia basket for mechanical lithotripsy. b Direct cholangioscopy in free-hand intubation using the "hooking technique." c The prepapillary segment with blurred visualization of the biliary mucosa by adherent sludge, inspissated bile, and disintegrated stone material.

Fig. 2. a Advancement up to the hilum failed due to gastric scope looping. Note marked biliary instrumentation-related submucosal hematoma with minor selflimited oozing. b Implementation of the "biopsy-forceps anchoring" technique to assist in hilar advancement (c) with full visualization of the CBD excluding remnant stone disease.
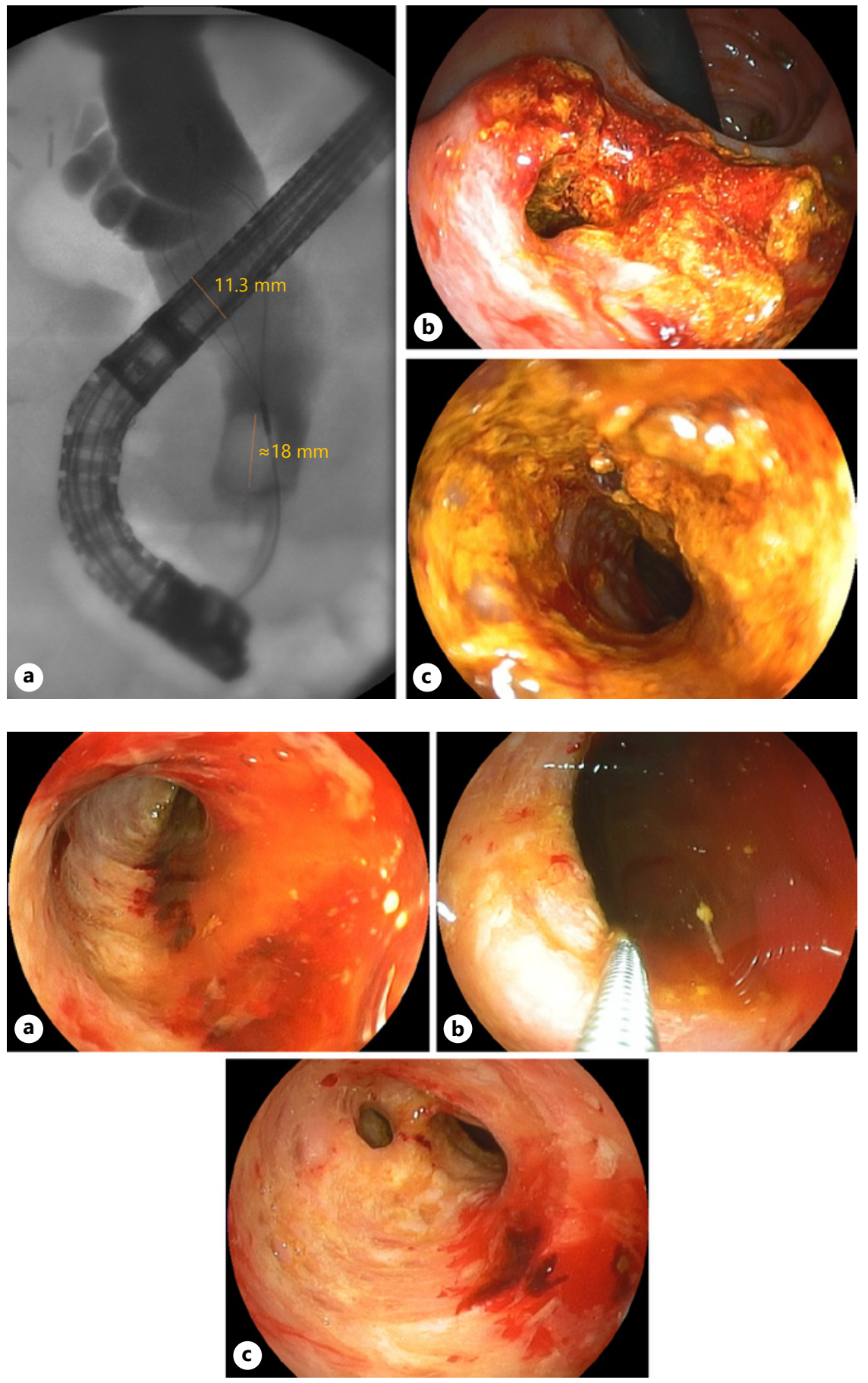

Funding Sources

No funding.

\section{References}

1 Zimmer V. Novel biopsy forceps anchoring technique for completion of direct cholangioscopy after freehand intubation. Dig Endosc. 2017 Jul; 29(5):638-9.

The author has no conflicts of interest to declare. 